$1-1-2018$

\title{
A Reformed Liberalism: Michael McConnell's Contributions to Christian Jurisprudence
}

\author{
Nathan Chapman \\ Assistant Professor of Law University of Georgia, nsc@uga.edu
}

University of Georgia School of Law

Research Paper Series

Paper No. 2018-15

Pbepress SSRN

\section{Repository Citation}

Nathan Chapman, A Reformed Liberalism: Michael McConnell's Contributions to Christian Jurisprudence Mark David Hall and Daniel Dresibach, Great Christian Jurists in American History (Cambridge University Press, forthcoming). (2018),

Available at: https://digitalcommons.law.uga.edu/fac_artchop/1160

This Article is brought to you for free and open access by the Faculty Scholarship at Digital Commons @ University of Georgia School of Law. It has been accepted for inclusion in Scholarly Works by an authorized administrator of Digital Commons @ University of Georgia School of Law. Please share how you have benefited from this access For more information, please contact tstriepe@uga.edu. 


\title{
A Reformed Liberalism: Michael McConnell's Contributions to Christian Jurisprudence
}

\author{
Nathan S. Chapman
}

\begin{abstract}
Americans mix Christianity and liberty so completely in their mind that it is nearly impossible to make them conceive one without the other; and, among them, this is not one of those sterile beliefs that the past bequeaths to the present and that seem more to vegetate deep in the soul than to live. ${ }^{2}$
\end{abstract}

Michael McConnell is one of the most influential jurists of his generation. As a scholar, judge, lawyer, and public intellectual, he has championed a modest legal conservatism that emphasizes judicial restraint, robust religious liberty, and space for religious voices in the public square. And he has done so as one of a handful of evangelical Christians in the upper echelons of the legal academy. $^{3}$

Most of McConnell's scholarship focuses on constitutional law and theory. Much of it explores how the U.S. Constitution protects religion. By contrast, relatively little of his work discusses the influence that religion has, or ought to have, on American constitutionalism. Nevertheless, in a handful of essays, McConnell has sketched a jurisprudence that emphasizes the continuities of Reformed (Calvinist) Christian theology, classical liberalism, and early U.S. constitutionalism. McConnell's "reformed liberalism," as this essay calls it, contrasts with secular liberalism, which dominates contemporary political theory, and with the views of liberalism skeptics. Though

\footnotetext{
${ }^{1}$ This essay is forthcoming in a volume edited by Mark David Hall and Daniel Dresibach on Great Christian Jurists in American History (Cambridge University Press). Thanks to Will Baude, Sam Bray, Daniel Dreisbach, Rick Garnett, and Mark David Hall for comments on prior drafts, and to T.J. Striepe for excellent library assistance. ${ }^{2}$ Alexis de Toqueville, Democracy in America: Historical-Critical Edition of "De la démocratie en Amérique," ed. Eduardo Nolla, trans. James T. Schleifer (Indianapolis: Liberty Fund, 2010), 2:476.

${ }^{3}$ See Alan Wolfe, "The Opening of the Evangelical Mind," The Atlantic (October 2000).
} 
McConnell does not a fully develop political theology, his view resembles other contemporary approaches to Christian liberalism, especially in its cautious optimism about republican constitutionalism.

For the most part, reformed liberalism does not surface in McConnell's other scholarship. This should be unsurprising; for McConnell, there is little daylight between the insights of Reformed theology, classical liberalism, the political assumptions of the founding generation, and the demands of contemporary constitutional decision-making. McConnell's theology is therefore consistent with, though it may not motivate, his constitutional jurisprudence.

This essay proceeds as follows: (I) a biographical sketch; (II) an introduction to McConnell's account of reformed liberalism; and (III) an overview of McConnell's major contributions to constitutional jurisprudence, with an analysis of how they correspond to reformed liberalism. At the outset, a brief word about my relationship with McConnell: I worked with him for three years at Stanford University's Constitutional Law Center, we have co-authored an article, and we are friends, but this essay is based entirely on information that is publicly available.

I.

McConnell's career was exceptional from the start. He grew up in Kentucky, graduated in 1976 from Michigan State University's James Madison College, and attended the University of Chicago Law School. Geoffrey Stone, a leading First Amendment scholar, said that McConnell "was one of the very few students I had that I knew I wanted to hire on the faculty within a few weeks of his arrival.” “[I]n hope of somewhat moderating Mike’s very strong conservative bent,” Stone "arranged clerkships after law school with the same two judges for whom [he] had clerked, both of whom were very liberal.”

\footnotetext{
${ }^{4}$ Eric Herman, “Former U of C prof on everyone's short court list: socially conservative judge has earned backing of liberals," Chicago Sun-Times (July 11, 2005), 65.
} 
Stone got everything he wanted except a political conversion. McConnell clerked for two of the most renowned federal judges, J. Skelly Wright on the D.C. Circuit Court of Appeals and William Brennan on the United States Supreme Court. In 1985, he returned to teach at his alma mater.

McConnell was aware that he was part of a "counter-revolution in legal thought." ${ }^{, 5}$ Since the New Deal, left-liberals had dominated American constitutional jurisprudence, especially in the academy. ${ }^{6}$ As McConnell explained in a 1987 essay in Policy Review, for generations liberal judges had deferred to legislation that advanced their ideals and, in the name of a "living Constitution," had invalidated legislation that did not. "Today," however, "conservative ideas increasingly set the terms of debate." Specifically, McConnell explained that there were four schools of conservative legal thought, each with its own principles and tensions with the others: "traditional jurisprudential conservatives," focused on judicial restraint; "libertarians," committed to "individual liberties" and "hostility to big government"; "the law and economics movement," with a "rigorous pursuit of economic efficiency"; and "social conservatives," attached "to community and traditional moral values."

The University of Chicago was ground zero for the conservative legal movement, leading the development of law and economics theory and boasting several influential libertarians. At the time, however, and to this day, McConnell was one of the only members of an elite law school faculty to write constitutional scholarship as a social conservative. ${ }^{9}$ Given his intellectual background, and his position at Chicago, it is unsurprising that McConnell's scholarship has often bridged the four

\footnotetext{
${ }^{5}$ Michael W. McConnell, "The Counter-Revolution in Legal Thought: Four Conservative Ideas Are Setting the Terms of Debate," Policy Review (Summer 1987): 18.

${ }^{6}$ See generally Laura Kalman, The Strange Career of Legal Liberalism (New Haven: Yale University Press, 1998).

${ }^{7}$ McConnell, "The Counter-Revolution," 18.

${ }^{8}$ Ibid.

${ }^{9}$ During this era Stephen Carter, Professor at Yale Law School, also wrote as a social conservative. See Stephen L. Carter, The Culture of Disbelief: How American Law and Politics Trivialize Religious Devotion (New York: Doubleday, 1993).
} 
schools of conservative thought, emphasizing their overlapping commitments and deemphasizing the tensions among them. As one historian has noted, McConnell has served as a link between otherwise disparate conservative groups..$^{10}$ While he has self-consciously sought to build intellectual consensus, McConnell has occasionally taken positions that put him at odds with other conservative thinkers, especially libertarians. He has, for instance, consistently defended the constitutionality of legislative prohibitions on conduct such as abortion and physician-assisted suicide that are difficult to square with contemporary libertarianism.

At Chicago, McConnell's constitutional jurisprudence began to take shape. Against "living constitutionalists” he argued for judicial adherence to the historical understanding of the constitutional text. Against those who demanded a strict separation of church and state he developed a subtle account of the Religion Clauses centered on the accommodation of private religious exercise. And against those who would shove religious views to the margin of public life, he argued for the priority of religious practice, expression, and political engagement. As this essay suggests, for McConnell, each of these positions is supported by classical liberalism, which in turn is supported by reformed Christian theology.

In 1997, McConnell took a position teaching law at the University of Utah. He taught there for five years before President George W. Bush nominated him to a vacancy on the Tenth Circuit Court of Appeals. Although liberal groups opposed his appointment based on his positions on abortion and religious liberty, he received broad support from law professors, liberal and conservative alike, and the Senate unanimously voted to confirm him.

On the court, McConnell sat on panels with other appellate judges, reviewing the decisions of trial courts that raised a variety of legal issues. From 2002 to 2009 he authored 90 opinions. The

\footnotetext{
${ }^{10}$ Ann Southworth, Lawyers of the Right: Professionalizing the Conservative Coalition (Chicago: University of Chicago Press, 2008), 45-46, 201 n.9.
} 
Supreme Court considered four of them, agreeing with McConnell's opinion in each." According to many accounts in the media, McConnell was on President George W. Bush's "short list" of potential Supreme Court appointees, but that was not to be..$^{12}$ In 2009, McConnell stepped down from the bench and joined the faculty of Stanford Law School, where he is the Director of the Stanford Constitutional Law Center.

As McConnell's career has taken him from one institution to another, he has maintained several commitments. First, he has consistently practiced law at the highest level. Before entering the academy, he served as Assistant General Counsel for the Office of Management and Budget, which oversees the economics of the federal government, and as Assistant to the Solicitor General, the office of the Department of Justice that argues before the Supreme Court on behalf of the federal government. While teaching, McConnell has worked with Kirkland \& Ellis and Mayer, Brown, \& Platt, two of the most prestigious litigation groups in the nation, authored numerous briefs, and personally argued fifteen cases before the Supreme Court, including a number of important religious liberty cases. ${ }^{13}$ Considering his practice alone, McConnell has had an extraordinary career in the law.

\footnotetext{
${ }^{11}$ See Pleasant Grove City v. Summum, 555 U.S. 460 (2009) (holding that a city's decision to accept one privately-donated monument and reject another did not violate the donors' free speech rights); Fernandez-Vargas v. Gonzalez, 548 U.S. 30 (2008) (interpreting a provision of an immigration statute); Begay v. United States, 553 U.S. 137 (2008) (holding that driving while intoxicated, a felony under New Mexico law, is not a "violent felony" under the federal Armed Career Criminal Act); O Centro Espirita Beneficiente Uniao do Vegetal v. Ashcroft, 546 U.S. 418 (2006) (holding that the a religious group has a statutory right to use otherwise illegal hallucinogenic tea for ceremonial purposes).

12 David Newman and Emily Bazelon, "The Supreme Court Shortlist: The Views of the Likely Candidates," Slate (July 1, 2005).

${ }^{13}$ See Christian Legal Soc'y v. Martinez, 130 S.Ct. 2971 (2010) (holding, contrary to McConnell's client, that the University of California Hastings School of Law could defund the Christian Legal Society student group because it imposed requirements on its members and leadership that effectively excluded sexually active gays and lesbians); Mitchell v. Helms, 530 U.S. 793 (2000) (holding that the First Amendment did not prohibit the federal government from making loans to religious schools for "secular, neutral, and non ideological" programs);
} 
Second, McConnell has consistently spotted talent and mentored young lawyers. After working with an especially gifted editor of the Harvard Law Review, McConnell suggested him for a position at the University of Chicago. That's how Barack Obama got his first job after law school. ${ }^{14}$ As a professor and judge, McConnell has mentored hundreds of young lawyers, a number of whom now hold tenure-track positions in leading law schools.

Third, McConnell has always been engaged in civic leadership. He has served on boards of directors for a variety of schools, clinics, and religious liberty committees. From 2007 to 2009 he was an elder at First Presbyterian Church (U.S.A.), Salt Lake City.

II.

Though McConnell's greatest influence as a scholar has been in the field of constitutional jurisprudence, he has also sketched the outline of a political theory that this essay refers to as “reformed liberalism.” According to McConnell, reformed Protestant theology, classical liberalism, and the principles that animated the framing of the U.S. Constitution are mutually reinforcing. This vision is distinctive among modern political theorists and casts light on McConnell's constitutional jurisprudence.

At the outset it is worth noting where McConnell's account differs from dominant secular and Christian political theories. By the end of the 20th century, liberals welcomed "liberty of conscience" as a right to maintain private religious beliefs, but sought to all but banish those beliefs

Rosenberger v. Univ. of Va., 515 U.S. 819 (1995) (holding that the Free Speech Clause prohibits the University of Virginia from declining to fund a student periodical simply because it has a religious viewpoint); Jimmy Swaggert Ministries v. Bd. of Equalization, 493 U.S. 378 (1990) (holding, contrary to McConnell's client, that the First Amendment does not prohibit a state from imposing a sales tax on a Christian ministry's publications).

${ }^{14}$ Jodi Kantor, “Teaching law, testing ideas, Obama stood apart," New York Times (July 30, 2008). 
from the public sphere. ${ }^{15}$ (Since 9-11, some liberals have begun to rethink religion's proper place in public discourse. ${ }^{16}$ While liberalism was abandoning Christianity, some Christian thinkers returned the favor. Because the modern liberal state has rejected traditional moral reasoning, academics such as Alisdair MacIntyre have argued that its pretense to the pursuit of justice is not only incoherent but also manifestly unjust. ${ }^{17}$ Others contend that the liberal state, as it has come to claim the exclusive loyalty of its citizens and to depend on the exercise of violence, is inconsistent with the demands of Christian discipleship. ${ }^{18}$ Against both of these approaches to the relationship of religion and liberalism, McConnell has emphasized the compatibility, even symbiosis, of robust religious exercise and limited government.

In “Old Liberalism, New Liberalism, and People of Faith,” McConnell identified three "doctrines of Christianity" that "point in the direction of liberalism," and argued that, "historically, liberalism was a product of those Christian impulses." ${ }^{19}$ He thus united Christian belief and the classical liberalism that influenced the constitutional framers, paving the way for a constitutional jurisprudence that complements reformed Protestant theology. The four doctrines and their liberal

15 See John Rawls, “The Idea of Public Reason Revisited," University of Chicago Law Review 64 (1997): 765; Richard Rorty, "Religion as Conversation-Stopper," in The Ethics of Citizenship: Liberal Democracy and Religious Convictions, J. Caleb Clanton ed. (Waco: Baylor University Press, 2009).

${ }^{16}$ See An Awareness of What is Missing: Faith and Reason in a Post-Secular Age, Jurgen Habermas ed., Ciaran Cronin trans. (Cambridge: Polity Press, 2010); Mark Lilla, The Stillborn God: Religion, Politics, and the Modern West (New York: Alfred A. Knopf, 2007). Some nonreligious liberals have been more sanguine about the possibility of religious engagement in public discourse. See Jeffrey Stout, Democracy and Tradition (Princeton: Princeton University Press, 2004).

${ }^{17}$ See Alisdair MacIntyre, After Virtue: A Study in Moral Theory (Notre Dame: University of Notre Dame Press, 1981).

${ }^{18}$ See Stanley Hauerwas, The Peaceable Kingdom: A Primer in Christian Ethics (Notre Dame: University of Notre Dame Press, 1983); John Howard Yoder, The Politics of Jesus (Grand Rapids: Wm. B. Eerdmans, 1972).

${ }^{19}$ McConnell, "Old Liberalism, New Liberalism, and People of Faith, in Christian Perspectives," in Christian Perspectives on Legal Thought, Michael W. McConnell, Robert F. Cochran, Jr., \& Angela Carmella eds. (New Haven: Yale University Press, 2001), 6-7. 
implications are: (1) the doctrine of sin and the separation of powers; (2) the doctrine of "two kingdoms" and the separation of church and state; (3) the doctrine of individual conscience and religious liberty; and (4) the priesthood of all believers and personal equality. The last two, as McConnell explained in a speech before the Vatican, are especially central to reformed Protestantism. $^{20}$

According to McConnell, "[P]erhaps the most fundamental connection between liberalism and Christianity is their common belief in the pervasive and ineradicable nature of $\sin ^{.{ }^{21}}$ Sin, in the Christian tradition, is not only the failure to live up to God's commands, but, perhaps more importantly, the inability to do so without God's grace. McConnell linked the doctrine of sin to "It]he central insight of liberal politics," "that all human beings and human institutions are prone to abuse of power. That is why liberal constitutionalism insists on dividing power and on creating checks and balances." ${ }^{22}$

To illustrate liberalism's assumption of human fallibility, McConnell pointed to The Federalist. ${ }^{23}$ One of the key principles of the United States Constitution, explained John Jay, James Madison, and Alexander Hamilton, is the distribution of power among three federal departments and between the federal government and the states. By this vertical and horizontal division of power, a "double security arises to the rights of the people.” Each government, and each

\footnotetext{
${ }^{20}$ McConnell, "Theological Foundations of the Religion Clauses of the First Amendment to the United States of America," in Secularismo e Liberta Religiosa (1998), 193, 194 ("Many of the same concerns for Christian liberty that inspired Protestant Christians to deny the ecclesiastical authority of Rome, rightly or wrongly, also lay behind their denial of the civil and ecclesiastical authority of their own legislatures in matters of religion.").

${ }^{21}$ McConnell, "Old Liberalism," 7.

${ }^{22}$ Ibid., 7.

${ }^{23}$ Ibid., 7.
} 
department in that government, will seek its own power; none will have it absolutely. In this way, Madison wrote, “ambition [will] be made to counteract ambition." ${ }^{24}$

By linking the doctrine of sin to The Federalist, McConnell subtly suggests that human sinfulness is reflected not only in classical liberalism, but also in the logic and structure of the U.S. Constitution. As an apology for the Constitution by some of the men who had a hand in drafting it, The Federalist is a starting point for jurists who seek the original understanding of the constitutional text. McConnell thus connected the dots between reformed Protestantism, liberalism, and the original understanding the U.S. Constitution.

The doctrine of sin leads McConnell to contrast "Christian politics” with "utopian politics.” Because "[w]e will not bring about the Kingdom of Heaven on this earth through our political efforts," "Christian politics should be antiutopian in character." "Utopian politics” is "dangerous and deceptive," even "a kind of idolatry," because it falsely promises governmental solutions to fundamental human problems but leads inevitably to "tyranny." Power, unchecked, begets abuse. Christians and classical liberals alike "take human nature as given, and make modest efforts to improve community life at the margin." ${ }^{25}$

The second Christian doctrine that McConnell identified as part of the "liberal theory of government" is the doctrine of two kingdoms, the view that God divided authority over human affairs between the church and the secular government. The doctrine of two kingdoms developed over the course of western political theology, from Augustine of Hippo to John Calvin. In the hands of the Protestant reformers, it was understood to be God's distribution of jurisdictional authority between temporal rulers and the church. Neither had complete control over human affairs, and each had limited control over the other.

${ }^{24}$ The Federalist No. 51 (Madison), in The Federalist (The Gideon Edition), George W. Carey and James McClellan eds. (Indianapolis: Liberty Fund, 2001), 268.

${ }^{25}$ McConnell, "Old Liberalism," 8. 
The most obvious application of this doctrine in liberal theory is the separation of church and state. Thus, McConnell argued, "[t]he two-kingdoms view is at the heart of our First Amendment. ${ }^{{ }^{26}}$ For this he cites John Locke, who translated the reformed Protestant version of the doctrine of two kingdoms into an argument for religious liberty. ${ }^{27}$

McConnell suggested another constitutional implication of the Christian doctrine of two kingdoms: a general commitment to a limited government. "If the state does not have power over the church, it follows that the power of the state is limited." Thus the "separation of church from state is the most powerful possible refutation of the notion that the political sphere is omnicompetent." ${ }^{28}$ In "Old Liberalism” he does not elaborate on this connection, and that is probably just as well. The doctrine of two kingdoms was not, at bottom, about limited government. It was about understanding the allocation of authority between two governments. Christian thought does not postulate a realm beyond government; the question is who governs what.

"A third theological notion at the foundation of liberalism," McConnell argues, "is the idea of primacy of conscience.” Championed by Martin Luther and John Calvin, the reformed notion is that each individual is responsible for determining and responding freely to God's will by faith. While this notion was politically destabilizing, it also held the seeds of religious freedom. As liberal theorists concluded, "it is literally impossible as a theological matter for government power to improve a citizen’s spiritual state." ${ }^{29}$ Put differently, "coerced faith is no faith at all."

McConnell discusses the Virginia “act for establishing religious freedom” as an example of the primacy of conscience at work in the founding-era liberal political project. Thomas Jefferson, a

\footnotetext{
26 Ibid., 10.

${ }^{27}$ Ibid., 11.

${ }^{28}$ Ibid., 10. See Michael W. McConnell, "Religion and Its Relation to Limited Government," Harvard Journal of Law and Public Policy 33 (2010): 943; Michael W. McConnell, "Non-State Governance," Utah Law Review (2010): 7.

${ }^{29}$ McConnell, "Old Liberalism," 13.

${ }^{30}$ McConnell, "Theological Foundations," 199.
} 
Deist, authored the bill, which was a precursor of the First Amendment. ${ }^{31}$ The bill ended statemandated contributions to churches. The first paragraph, which spells out the bill's assumptions, is a powerful statement of the theological underpinnings of the liberal commitment to religious freedom:

Whereas, Almighty God hath Created the mind free; That all attempts to influence it by temporal punishments or burthens, or by civil incapacities tend only to beget habits of hypocrisy and meanness, and therefore are a departure from the plan of the holy author of our religion, who being Lord, both of body and mind yet chose not to propagate it by coercions on either, as was in his Almighty power to do so ... ${ }^{32}$

Elsewhere McConnell relied on these concepts to urge the Vatican to "appreciate the significance of beginning the argument for religious liberty unashamedly with the proposition that Almighty God hath made the mind free, and to join with Elisha Williams in his insistence that Christ be King in His own Kingdom." ${ }^{33}$

In “Old Liberalism,” McConnell further argues that the doctrine of conscience "implies and leads to liberty in other matters essential to human flourishing: each person is free not just to worship but to pursue the good life in the manner and season most agreeable to his or her conscience." "To the extent that God's will affects all of life," he argued, "then the principle of freedom must apply to all of life." ${ }^{34}$ Given his commitment to Christian conscience, however, McConnell disavowed libertinism, which may arise from agnosticism about the good. In the "early

\footnotetext{
${ }^{31}$ See Everson v. Bd. of Ed., 330 U.S. 1 (1947). For an argument that Jefferson's bill did not influence those who drafted and ratified the First Amendment, see, e.g., Mark David Hall, "Madison's Memorial and Remonstrance, Jefferson's Statute for Religious Liberty, and the Creation of the First Amendment," American Political Thought 3 (2014): 32-63.

32 William Lee Miller, The First Liberty: Religion and the American Republic (Washington, D.C.: Georgetown University Press, 2003): 255-57.

${ }^{33}$ Ibid., 203.

34 McConnell, “Old Liberalism," 14.
} 
liberal conception," he writes, "freedom was the freedom to do the right." ${ }^{35}$ This emphasis puts reformed liberalism in tension with the libertarian offshoots of classical liberalism.

The final Christian doctrine that McConnell identified as an influence on classical liberalism is the "priesthood of all believers." ${ }^{\prime 6}$ As the Apostle Paul put it, Christ died for all; in him "[t]here is no longer Jew or Greek, there is no longer slave or free, there is no longer male and female. ${ }^{{ }^{37}}$ For the Protestant reformers the doctrine of spiritual equality had implications for salvation and for the nature of the church. They believed the Bible to be "a sufficient revelation of the truth to all men, and that all have the capacity to read and understand it without the mediation of earthly authorities." Thus "all people are equal in the most fundamental sense-in their capacity to perceive the will of God and to act upon it." ${ }^{38}$

The ecclesiastical implications of the priesthood of all believers had a direct influence on classical liberal theories of popular sovereignty and constitutionalism. Equality of spiritual judgment implied equality of responsibility for church affairs. From this premise arose the reformed doctrine of covenant, "wherein a group of individuals constitute themselves as a body by mutual consent, based on shared convictions, with God as witness and ultimate authority.” ${ }^{39}$

The conceptual as well as the historical connections between the doctrine of covenant and liberal theories of political sovereignty are clear. As McConnell explains:

In its secular garb, the notion of covenant lies behind the political idea of the consent of the governed. If all persons are equally capable of perceiving the good and acting on it, then no

35 Ibid., 15.

36 Ibid., 15.

${ }^{37}$ Galatians 3:28 (New Revised Standard Version).

38 McConnell, "Old Liberalism," 15.

39 Ibid., 15. See Michael W. McConnell, "Calvinism and Liberty: Reformed influences on America's founding principles," review of The Reformation of Rights: Law, Religion, and Human Rights in Early Modern Calvinism, by John Witte, Jr., Books and Culture (Jan./Feb. 2009). 
one has a natural right to rule over another, and just government can be based only upon

consent. In this sense, democracy was a secularization of the movement away from a

hierarchical church structure and toward congregational ecclesiology. ${ }^{40}$

Enter the United States Constitution, the first national charter to memorialize and implement popular sovereignty. In the early years of the republic, McConnell noted, reformed theology, classical liberalism, and constitutionalism walked hand in hand. Religion was not relegated to private, non-political affairs. Rather it provided the conceptual and moral underpinning for liberal republicanism. The expansion of equality and enfranchisement owed as much to the theology and religious fervor of the Great Awakenings as to the anthropology of the Enlightenment. ${ }^{41}$

McConnell's account of "reformed liberalism," though merely a sketch, is innovative. While other Christian thinkers have developed more elaborate theories attempting to integrate Christianity and contemporary liberalism, McConnell's deserves to be read alongside them. ${ }^{42}$ Few have given more thought to the Protestant bases of religious liberty, ${ }^{43}$ or done more to develop a constitutional jurisprudence that aligns with an account of Christian liberalism. ${ }^{4}$

\section{III.}

\footnotetext{
${ }^{40}$ McConnell, "Old Liberalism," 16; see Gordon Wood, The Radicalism of the American Revolution (New York: Vintage, 1991), 230, 235.

${ }^{41}$ McConnell, "Old Liberalism," 17; see Nathan O. Hatch, The Democratization of American Christianity (New Haven: Yale University Press, 1989).

${ }^{42}$ See Nicholas Wolterstorff, The Mighty and the Almighty: An Essay in Political Theology (Cambridge: Cambridge University Press, 2012); Eric Gregory, Politics and the Order of Love: An Augustinian Ethic of Democratic Citizenship (Chicago: University of Chicago Press, 2008); Oliver O’Donovan, The Ways of Judgment (Grand Rapids, MI: Wm. B. Eerdmans, 2008); Charles Matthewes, A Theology of Public Life (Cambridge: Cambridge University Press, 2007). ${ }^{43}$ See Nicholas Wolterstorff, "A Religious Argument for the Civil Right to Freedom of Religious Exercise, Drawn from American History," Wake Forest Law Review 36 (2001): 535; John Witte, Jr., "The Essential Rights and Liberties of Religion in the American Constitutional Experiment," Notre Dame Law Review 71 (1999): 372.

${ }^{44}$ See H. Jefferson Powell, "The Earthly Peace of the Liberal Republic," in Christian Perspectives; H. Jefferson Powell, The Moral Tradition of American Constitutionalism: A Theological Interpretation (Durham, NC: Duke University Press, 1993).
} 
McConnell's greatest contributions to constitutional jurisprudence have been sustained arguments for religious liberty, for an equal place for religion in public life, and for judicial deference to the democratic process where the Constitution is silent about contested moral issues. For each, he appeals to history, American constitutional tradition, and fundamental principles of republican political theory. Each of these themes is consonant with, though independent of, his notion of reformed liberalism.

\section{A. Religious Accommodations}

McConnell is perhaps best known in the legal academy for his scholarship on religious liberty. Early in his career he developed a theory of religious liberty that "changed the terms of debate." Since mid-century, the Supreme Court had held that government action with the purpose or primary effect of advancing religion violated the Establishment Clause. ${ }^{46}$ Many scholars defended this view by arguing that the Religion Clauses required "strict separation" between church and state.

But McConnell noticed that as the government reaches into nearly every facet of public life, it regulates conduct by individuals and groups that, though not originating with the government, nonetheless occurs in public. When the government organizes and regulates private conduct that occurs in public-schools, churches, public events, and the like-must the government ignore, or even be hostile toward, the religious exercise of those parties? McConnell argued that some government action that facilitates religion does not amount to an establishment of religion, but rather is best understood to accommodate private religious exercise in a way that is entirely consistent with the Religion Clauses. ${ }^{47}$

${ }^{45}$ Mark Tushnet, “Accommodation of Religion Thirty Years On," Harvard Journal of Law \& Gender 38 (2015): 1, 7-8.

${ }^{46}$ Lemon v. Kurtzman, 403 U.S. 602 (1971).

${ }^{47}$ Michael W. McConnell, “Accommodation of Religion,” Supreme Court Review 1985: 1; Michael W. McConnell, "Accommodation of Religion: An Update and a Response to the Critics," George Washington Law Review 60 (1992): 685. 
The theory had the benefit of making sense of a number of longstanding American traditions and statutes that would have violated a strict separation of church and state but that, given the government's breadth of regulation, could be reformulated as accommodations of religion. Take for instance the government's provision of religious chaplains for members of the military or prisoners. On the one hand, the government's employment of military and prison chaplains promotes religion-especially among those who may be particularly susceptible to the government's exercise of power. On the other hand, when the government assigns someone to a ship, base, or prison, it deprives him of access to his minister, congregation, and religious practices. Rather than giving a particular religious belief or practice the state's imprimatur, then, providing a chaplain accommodates the sailor, soldier, and prisoner's private religious exercise.

McConnell's theory also at least partially reconciles the Supreme Court's doctrine under the Establishment and Free Exercise Clauses. At the time, the Court held that the Free Exercise Clause requires an accommodation from a governmental regulation that imposes a substantial burden on religious exercise when the regulation was unnecessary to achieve a compelling governmental interest. ${ }^{48}$ This interpretation of the Free Exercise Clause probably-ironicallyamounted to a violation of the Court's interpretation at that time of the Establishment Clause, which prohibited the government from acting with the purpose or principal effect of advancing religion. A theory of government accommodations reconciles exemptions for religious exercise with a commitment to the government's neutrality among religions by explaining that even-handed accommodations simply remove government-imposed burdens from religious exercise rather than promoting a particular religious belief or practice.

McConnell also wrote a book-length article arguing that the original history of the Free Exercise Clause is consistent with the view that the Clause requires accommodations from general

${ }^{48}$ Sherbert v. Verner, 374 U.S. 398 (1963). 
laws that burden religious exercise. ${ }^{49}$ At the time, the article would have reinforced the Court's interpretation of the Free Exercise Clause. That changed, however, the same year the article appeared.

In the landmark decision Employment Division v. Smith (1990), the Supreme Court held that the Free Exercise Clause does not provide an accommodation from a religiously neutral law of general applicability, regardless whether the law imposes a substantial burden on religious exercise. $^{50}$ The case was about whether members of a Native American church who used peyote as a sacrament were entitled to an accommodation from laws prohibiting the possession and use of controlled substances. Departing from longstanding doctrine, the Court said no, and it has never backed away from this decision. The political backlash to the case was swift and decisive. A nearunanimous Congress passed and President Clinton signed the Religious Freedom Restoration Act (RFRA). The Act reinstated accommodations from laws that unnecessarily place a substantial burden on religious exercise..$^{.1}$ From the beginning the Act has received criticism from scholars who believe that it amounts to an unconstitutional establishment of religion. While McConnell's historical review of free exercise did not convince the Court to keep its doctrine of accommodations under the Constitution, it nonetheless provided crucial support for the constitutionality of government efforts, like RFRA, that provide such accommodations by statute.

\footnotetext{
${ }^{49}$ Michael W. McConnell, "The Origins and Historical Understanding of Free Exercise of Religion," Harvard Law Review 103 (1990): 1409; see Michael W. McConnell, "Establishment and Disestablishment at the Founding, Part I: Establishment of Religion," William and Mary Law Review 44 (2003): 2105. McConnell's Harvard Law Review article prompted several rebuttals of his interpretation of the history. See Ellis West, "The Right to Religion-Based Exemptions in Early America: The Case of Conscientious Objectors to Conscription," Journal of Law and Religion, 10 (1993-1994): 367-401; Philip A. Hamburger, "A Constitutional Right of Religious Exemption: An Historical Perspective," George Washington Law Review 60 (1992): 915.

${ }^{50}$ Employment Division v. Smith, 494 U.S. 872 (1990).

${ }^{51}$ Pub. L. No. 103-141, 107 Stat. 1488 (1993), codified at 42 U.S.C. $§ 2000 b b$ through 42 U.S.C. $\S 2000 \mathrm{bb}-4$.
} 
Although McConnell rarely expressly makes the connection, his theory of religious accommodations is consistent with his view of reformed liberalism. He painstakingly reviewed the history of the Free Exercise Clause, concluding that accommodations were consistent with that history, though that history may not have required them. By doing so, he tied contemporary accommodationism directly to the political theory that animated the founding era, which he believes to be consistent with reformed liberalism. For those who may be unmoved by evidence of the founders' commitment to religious accommodations, however, McConnell also provided an important conceptual argument that linked contemporary accommodations to the founders' broader understanding of the government's role in public life. "[T]he old paradigm of 'strict separation' under the Establishment Clause has had to give way to such ideas as 'equal access,' 'neutral funding,' and 'accommodation.'” Otherwise the government's steady growth "would have been a relentless engine of secularization. ${ }^{{ }_{52}^{2}}$ McConnell thus suggests that religious accommodations, though not widely practiced at the founding, may be more consistent with classical liberalism, and thus with the spirit of reformed Protestantism, than would a continuing commitment to a strict separation of church and state..$^{53}$

\section{B. Religious Reasons in Public Discourse}

McConnell has also been one of the most influential legal scholars to respond forcefully to the argument that religion has no place in public discourse. That theory, advanced most famously by the philosopher John Rawls, holds that members of a liberal democracy are obligated to give one another reasons that could, in principle, be acceptable to others. ${ }^{54}$ According to some versions of this notion, a citizen may not advance religious reasons for law or policy because non-believers

\footnotetext{
52 McConnell, “Old Liberalism," 21.

${ }^{53}$ Ibid., 23-24.

${ }^{54}$ Rawls, "Public Reason"; John Rawls, Political Liberalism (New York: Columbia University Press, 2005).
} 
could not accept them..$^{55}$ The principle has important implications. All legislation should be based on non-religious reasons, including, somewhat ironically, perhaps, legislation that facilitates religious exercise. More importantly, perhaps, the notion relegates religion to a sphere of private belief and exercise, expelling it from public discourse about politics and morality, whether in journals, classrooms, political campaigns, or ballot boxes.

McConnell has forcefully opposed this account of liberalism, maintaining instead that citizens are entitled to give one another their reasons for favoring or opposing public policy, even when those reasons are based on religious beliefs. Indeed, citizens are entitled to recruit others to their religious views, including their views about public policy. Religious reasons are neither more nor less susceptible than any other kinds of reasons of gaining the assent of those who do not share all of the presumptions that underlie them. ${ }^{56}$

A chief implication of McConnell's view is that the government should not disfavor private religious education or students' exercise of religion within public schools. Schools are the nurseries of public discourse. When the government puts a thumb on the scales against religious education or private religious exercise it systematically marginalizes religious voices in the public sphere for generations. The history of American public education and its use as a tool to promote the majority's religious sentiments is long, complicated, and turns a great deal on local norms. McConnell's theory of accommodations emphasizes that the First Amendment should be

\footnotetext{
55 John Rawls originally advanced such a view of "public reason." A number of critics noted that this view would have eliminated the religious arguments of abolitionists and civil rights advocates. Rawls therefore revised his view to permit a citizen to advance a reasonable religious doctrine in public reasoning so long as she follows likewise advances a "public reason" sufficient to support her point. See Rawls, Political Liberalism xlix-1; see generally John Rawls, "The Idea of Public Reason Revisited," University of Chicago Law Review, 64 (1997): 765-807. ${ }^{56}$ Michael W. McConnell, "Five Reasons to Reject the Claim that Religious Arguments Should be Excluded from Democratic Deliberation," Utah Law Review (1999): 639; Michael W. McConnell, "Secular Reason and the Misguided Attempt to Exclude Religious Argument from Democratic Deliberation," Journal of Law Philosophy and Culture 1 (2007): 159.
} 
understood to require the government to provide even-handed support for education regardless of the parent and student's religious commitments. He has thus supported public vouchers so that poorer parents may choose to send their children to private religious schools. ${ }^{57}$ The current model, in which the government supplies only a religion-free education, gives only the wealthy the opportunity to educate their children according to their religious beliefs.

Within public schools, too, McConnell has argued for the right of students to fully exercise their religions. In an important free speech and free exercise case before the Supreme Court, he successfully argued that religious student groups at public universities have the same right to use public funds to discuss their viewpoints that others have to discuss non-religious viewpoints. ${ }^{58}$

McConnell's argument that religion should have a place in public discourse is in line with his view of reformed liberalism. Reformed liberalism holds that God's sovereignty and care for humans are the most important bases of human decision making, and responding to God's truth and love will naturally shape one's views of public policy. Rather than sidelining religion, or assuming that it has uniform implications for public policy, reformed liberalism makes space for people to advance religious views-including the space to disagree about religion and to dispute its implications for the common good.

C. Judicial Humility and Democracy

McConnell's most broadly applicable contribution to constitutional jurisprudence has been to consistently urge the Supreme Court to exercise judicial humility. He has been one of a handful of scholars arguing for judicial self-restraint during an era when the Court has confidently asserted its

\footnotetext{
${ }^{57}$ Michael W. McConnell, "Education Disestablishment: Why Democratic Values Are Ill-Served by Democratic Control of Schooling," in Nomos XLII: Moral and Political Education, Stephen Macedo and Yael Tamir eds. (New York: New York University Press, 2002): 87; McConnell, "The Selective Funding Problem: Abortions and Religious Schools," Harvard Law Review 104 (1991): 989.

${ }^{58}$ Rosenberger v. University of Virginia, 515 U.S. 819 (1995).
} 
authority to enforce constitutional limits on the government even when those limits do not have a clear foundation in the Constitution's text and history.

The Supreme Court's constitutional interpretation, McConnell argues, should hew closely to the Constitution's text and historic understanding. ${ }^{59}$ When those touchstones do not foreclose a policy decision embodied in an act of Congress or a state law, the Court should defer to the People's policy preferences. The principles underlying the Constitution suggest that, where the Constitution is silent, or can reasonably be read to authorize certain legislation, the People should have their way. The Constitution creates a government by the People, not by the Court. When the Court enforces the Constitution, it is enforcing the will of the People expressed in that document. When it ventures beyond the Constitution's text, the Court usurps the People's authority to govern themselves. ${ }^{60}$

Put differently, policy determinations on contested moral issues that the Constitution's text and history do not resolve should be resolved from the bottom up, not from the top down. Republican constitutionalism is messy. It presumes the People will disagree about matters of first importance. And it provides that the People themselves will resolve those disputes through their duly elected representatives, subject to constant revision through continuing public debate. When the Court invalidates a law regulating conduct about which people have moral disagreements, such as abortion, it ends democratic engagement of the issue. The only way for the People to take the issue back from the Court is to enact a constitutional amendment, something the Constitution itself

\footnotetext{
${ }^{59}$ McConnell, “On Reading the Constitution,” Cornell Law Review 73 (1988): 359; McConnell, "Time, Institutions, and Interpretation," Boston University Law Review 95 (2015): 1745.

${ }^{60}$ See McConnell, "The Importance of Humility in Judicial Review: A Comment on Ronald Dworkin's 'Moral Reading' of the Constitution,” Fordham Law Review 65 (1997): 1269.
} 
makes a difficult task. The People should not have to gain a supermajority to govern themselves according to the terms of their fundamental charter. ${ }^{61}$

One of the longstanding disputes in constitutional law is whether, when, and why the Court should enforce individual rights that the Constitution does not expressly enumerate. While McConnell has generally argued that the People should have a free hand when the Constitution is silent, he has also argued that some rights may arise from longstanding practices of the people themselves-practices that the law has uniformly protected or allowed though the Constitution does not mention them. A family's right to raise and educate its own children may be one example. ${ }^{62} \mathrm{By}$ the same token, McConnell has argued that a number of rights the Supreme Court enforces against the states under the auspices of the Due Process Clause of the Fourteenth Amendment have little basis in the legal traditions and practices of the people. ${ }^{63}$ Such rights, he suggests, should have their source ultimately in the People, usually through the constitutional text they adopt, or, at a minimum, through unspoken expectations based on longstanding legal tradition. ${ }^{64}$

McConnell has been even-handed about the implications of judicial humility. From early in his career he has argued against the legitimacy of the Court's abortion jurisprudence on the ground that it lacks a firm basis in constitutional text, history, and tradition. This may be an unsurprising position for a social conservative. However, McConnell has been equally critical of "conservative" Supreme Court decisions when they do not arise from the Constitution's text and history. For instance, McConnell defended Chief Justice Roberts’ decision, controversial among some

${ }^{61}$ McConnell, "The Role of Democratic Politics in Transforming Moral Convictions Into Law," Yale Law Journal 98 (1989): 1503; see Michael W. McConnell, "Institutions and Interpretation: A Critique of City of Boerne v. Flores," Harvard Law Review 111 (1997): 153.

${ }^{62}$ Pierce v. Society of Sisters, 268 U.S. 510 (1925).

${ }^{63}$ Nathan S. Chapman \& Michael W. McConnell, "Due Process As Separation of Powers," Yale Law Journal 121 (2012): 1672.

${ }^{64}$ McConnell, "The Right to Die and the Jurisprudence of Tradition," Utah Law Review 1997:665; McConnell, "Ways to Think About Unenumerated Rights," University of Illinois Law Review (2013): 1985. 
conservatives, to uphold the "individual mandate" provision of the Affordable Care Act under Congress's Taxing Power." "Roberts's deft opinion," he wrote, “strikes a mighty blow for conservative constitutionalism, while bolstering the court's moral authority and reminding the country of the difference between law and politics. ${ }^{{ }_{66}}$ Likewise McConnell criticized the Court for invalidating part of the Voting Rights Act because he believed it rested on legal reasoning the conservative justices "made up."

McConnell's case for modest judicial review corresponds to reformed liberalism. All people, not just an elite class of lawyers and judges, have an equal right to determine the norms that will shape their society. The government's role is limited to enforcing those norms the People enact into law, subject to the strictures the People have imposed on the government through a written compact.

Where McConnell promotes a modest judicial review of government conduct that might restrict unenumerated rights, his jurisprudence is in tension with the principles and aims of a more libertarian approach to U.S. constitutionalism. This is, perhaps, the most important area of disagreement between McConnell and some other conservative legal scholars: in the name of popular sovereignty he has argued that the government should have latitude to restrict a wide range of individual conduct. This, too, is consistent with reformed liberalism, for it ensures that the People themselves are a check on the ambitions of a governing class, even a governing class of libertarians.

\author{
V. Conclusion
}

${ }^{65}$ Nat'l Fed. of Ind. Bus. v. Sebelius, 132 S.Ct. 2566 (2012).

${ }^{66}$ McConnell, "Chief Justice Roberts crafts a ruling more conservative than it looks." Reuters (June 29, 2012).

${ }^{67}$ Nina Totenberg, "Whose Term Was It? A Look Back At the Supreme Court" (includes an interview with Michael McConnell), National Public Radio: Morning Edition (July 5, 2013). 
McConnell's most enduring contributions to Christian jurisprudence are impossible to estimate. He is, one hopes, far from the close of his career. Perhaps he will more fully elaborate a theory of reformed liberalism and relate it to his contemporary constitutional jurisprudence. Or perhaps he will continue to call for a more modest approach to judicial review. However, he spends the remainder of his career, one can be sure that he will continue to advance, through his scholarship, lawyering, teaching, and op-eds, the "one point" he has "tried to make" "for most of [his] professional life": "the only tolerance worth having is tolerance for different understandings of the truth. A toleration based on skepticism, indifference or relativism is no tolerance at all. ${ }^{98} \mathrm{~A}$ reformed liberalism indeed.

${ }^{68}$ Michael W. McConnell, "We Worship the Same God You Do," in Professors Who Believe: The Spiritual Journeys of Christian Faculty, Paul M. Anderson ed. (Downers Grove, IL: InterVarsity Press, 1998), 204. 